\title{
Rare and Endemic Plants of the Relic Mountain of Sultan-Uvays
}

\author{
Rabiga X. Yesemuratova \\ Institute of Botany Academy Sciences Republic of Uzbekistan, Tashkent, Uzbekistan \\ Email: Esemuratovarabyga80@mail.ru
}

How to cite this paper: Yesemuratova, R.X. (2021) Rare and Endemic Plants of the Relic Mountain of Sultan-Uvays. American Journal of Plant Sciences, 12, 1-6. https://doi.org/10.4236/ajps.2021.121001

Received: December 3, 2020

Accepted: January 16, 2021

Published: January 19, 2021

Copyright $\odot 2021$ by author(s) and Scientific Research Publishing Inc. This work is licensed under the Creative Commons Attribution International License (CC BY 4.0).

http://creativecommons.org/licenses/by/4.0/

\begin{abstract}
The article studied rare and endemic plants scattered on the relic mountain of Sultan-Uvays. During the studies, the floristic list of the territory was also formed. Floristical studies revealed 497 species of vascular plants, belonging to 230 genera and 49 families. Investigated flora can be characterized by 1 endemic and 10 subendemic species should be included in the List of rare and endangered plants of Karakalpakistan as well as in the Red Data Book of Uzbekistan. It was found out that the populations of the studied species are in normal condition. Information obtained on the distribution of rare and endemic species is used in the preparation of plans for protection measures and monitoring studies, as well as in the preparation of the next editions of the flora of Uzbekistan and the red book of the Republic of Uzbekistan.
\end{abstract}

\section{Keywords}

Rare, Endemic, Flora, Sultan-Uvays, Kyzylkum

\section{Introduction}

Conservation of the plant world, especially rare, endangered and demanding plant species, is one of the global problems of studying the balanced use and conservation of biodiversity on Earth. The degree of threat of extinction of different species, of course, is not the same. First of all, endemic and relict plant species need protection. Rare and endemic plants are the most vulnerable component of the flora, as the loss of any of them means an irreparable loss for biodiversity as a whole. Therefore, their study and preservation are an important task. Among the rare species, the most important for conservation are subendemic species, whose range only slightly extends beyond Central Asia, and especially those that are universally rare or are particularly popular as collection sites [1]. In Uzbekistan, determination of the composition of natural flora on the basis of mod- 
ern research methods, assessment of the vegetation state, conservation and sustainable usage occupies a special place among the priority areas for biodiversity conservation. At this stage of intensive development of floristic studies and accumulation of a large array of new data, implementation of the system of research in order to preserve biodiversity is of great importance. In connection with this, it is important to improve and conduct floristic studies in areas of high anthropogenic disturbances. Kyzylkum and its relic mountains differ with the originality of floral composition as well as the presence of rare and endemic plant species. According to this, it is actual to preserve the flora of the territory. It must be emphasized that the study of the flora of the Relic Mountains located in the Sultan-Uvays.

\section{Purpose of the Study}

Distribution and evaluation of the rare and endemic plants of the relic mountain of Sultan-Uvays.

\section{Materials and Methods}

Rare and endemic species were identified on the basis of materials collected during field research, existing scientific sources and herbarium samples stored in the national herbarium of Uzbekistan (TASH). A critical analysis of herbarium materials stored in the TASH Fund revealed distributed in the Sultan-Uvays region, 1 endemic and 10 subendemic of which belong to the group of rare and endemic species.

\section{Study Area}

The Sulton-Uyavs relic-mountain range is located on the right side of the Amu-Darya river, being the westernmost of the mountain systems of Central Asia and, above all, the Western Tien Shan. It is also an isolated mountain range, which is part of the so-called "relic mountains of Kyzylkum" [2]. This ridge starts from the old Delta of the Amu-Darya and stretches in a narrow strip from East to West to lake Khojakul. It is approximately $40 \mathrm{~km}$ long and $10-15 \mathrm{~km}$ wide. In the Western part, the ridge stretches almost latitudinal first along the Amu Darya, and then goes from it to the East into the Kyzylkum desert. The Eastern part of the ridge is a system of low outcrops of Ayazkala (Figure 1).

The total area of Sultan-Uvays is $700 \mathrm{sq} \cdot \mathrm{km}$. the highest point is mount $\mathrm{Ka}$ ra-Chingil (485 $\mathrm{m}$ above sea level). Sultan-Uvays in the West splits into isolated hills: Sheikh Jeli, Kuyanchik, Zengebaba and Jumurtau. In the geomorphological sense, they are the remains of an ancient ridge composed of Paleozoic rocks. Sulton-Uvays is a mountain structure of a complex geological structure, which differs sharply in its structural and petrological features from similar formations of the same age developed in Central Asia. The Eastern part of Sultan-Uvays (East of Kyzylsay) is composed mainly of Ordovician and Silurian rocks, while the Western part of the region is represented almost exclusively by lower Devonian 


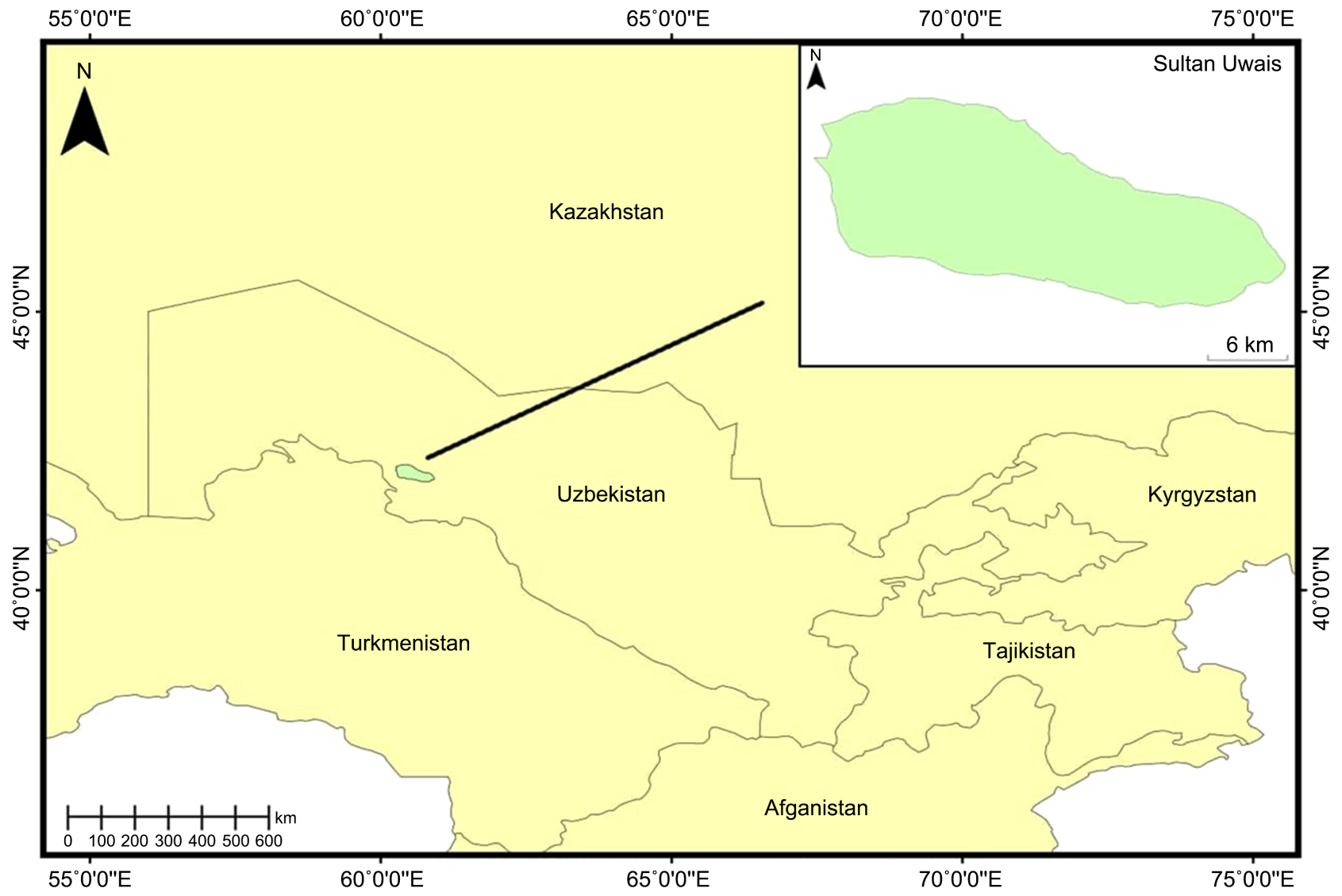

Figure 1. Study area.

tuff shales. The youngest granitoid intrusion in the region is confined to the southern part of the ridge. Cretaceous and Quaternary deposits have a fairly wide development in the southwestern part of Sultan-Uvays. For Sultan-Uvays tends to a number of relic hills-Zhaksy the Kokcha, Zhaman the Kokcha, Ayaz-Kala, has Karasankima, Bestobe, Kostobe. The direct continuation of the Sultan-Uvays on the left Bank of the Amu Darya is the remnant hill of Jumurtau. Sultan-Uvays is characterized by extreme low water content, deep groundwater occurrence, in which, as is commonly believed, capillary uplift and direct nutrition of plants are excluded [3].

\section{Result and Discussion}

The soils are sandy loam, loamy and gravelly. The climate of this area is dry, sharply continental. The vegetation cover here is completely dominated by groups of desert vegetation types and, above all, sagebrush. All the other dominant form only micrographically. Therefore, it is not possible to conduct any phytocenotic studies here due to the lack of full-fledged communities. E. P. Korovin [4] refers the lowlands of Sultan-Uvays to the Amu Darya district of the Central Kazakh province. R.V. Kamelin [5] attributed this ridge, along with all the remnants of Kyzylkum, to the mountain-middle Asian Botanical and geographical province. A more correct solution to the problem of zoning, the assignment of all the re- 
mains of Kyzylkum to the desert Turan province - was proposed by Uzbek botanists in the 21st century [6]. The absence of vertical zoning, the range of leading families and genera in the flora, as well as the composition of endemics indicates the desert nature of its flora, which still preserved rare mountain-middle Asian species.

One of the first botanists to visit Sultan-Uvays was the outstanding florist and taxonomist M. G. Popov, who collected in these mountains for only 7 days and examined only the southern slopes of the ridge. As a result of this visit, he published [7] the now classic article "Botanical and geographical sketch of the Sultanuizdag mountains", where he cites 121 species of vascular plants. Detailed studies of the flora of Karakalpakia began in the post-war years. B. Sh. Sherbayev [8] gives for all the remains of Karakalpak-506 species, and for Sultan-Uvays 444 species belonging to 226 genera and 51 families. R. Abdurakhmanov [9] in his geobotanical work cites only 240 species, And P. K. Zakirov [2], 230 species of higher plants from 131 genera and 32 families. As a result of 10 years of research, we have compiled a list of flora from species belonging to genera and families. Only 1 species (Lappula parvula Nabiev et Zakirov) should be considered strictly endemic to Sultan uwais. For such a small floristic area, this is a good indicator, and considering also 10 subendemic species, we can talk about the originality of this desert flora, which as a result of the most powerful processes of xerophilization in the Aral Sea region is strongly destroyed and impoverished from year to year. It is this fact that gives priority to the identification of endemic taxa, so necessary for the creation of a list of rare, endangered plant species of Karakalpakistan and the creation of the next new edition of the Red Book of Uzbekistan.

Among the subendemics, first of all, it is worth mentioning Allium rinae F. O. Khass., Shomuradov et Tojibaev, recently described from neighboring Bukantau. It is a vicar species replacing the mountain floras of Central Asia $A$. filidens Regel in Turan. Another 3 species of Astragalus also grow here: 2 species shared with Bukantau (Astragalus remanens Nabiev and A. holargyreus Popov), as well as $A$. centralis E. Sheld., described from Aktau (Kyzylkum). As a result of the typification of Astragalus [10], kuldzhuktau plants were assigned to another new species, A. kuldzhuktauense F. O. Khass., Shomuradov, Esankulov. The same floristic affinity with Bukantau is shown by subendimic species of compound Flowers-Scorzonera bungei Krasch. et Lipsch and S. gageoides Boiss., although the latter was also recorded in Kuldzhuktau. Among the ten endemic taxa of the Kyzylkum district, we note only rare and endangered populations of mountain-middle Asian Silene tomentella Schischk., Stipa aktauensis Roshev and Lepidium subcordatum Botsch. et Vved. And finally, another rare species described from Sultan-Uvays, Asparagus turkestanicus Popov also grows on Ustyurt. The most interesting Turan relict endemic is Xylosalsola chiwensis (Popov) Akhani \& Roalson, along with the Kyzylkum remnant endemics Lagochillus vvedenskyi Kamelin et Zuckerw and Ferula kyzylkumica Korov. They also grow here (Figure 2). 


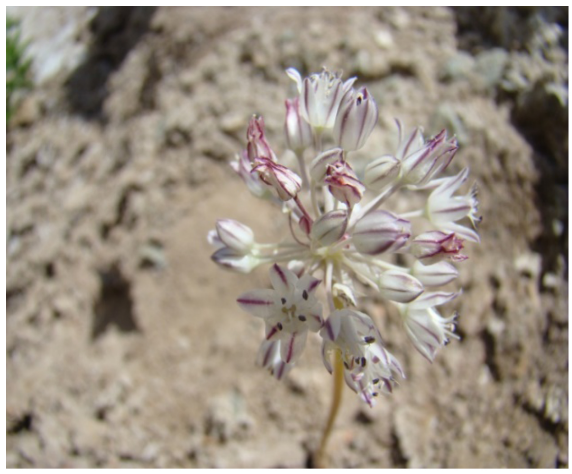

Allium rinae $\mathrm{F}$. O. Khass., Shomuradov \& Tojibaev

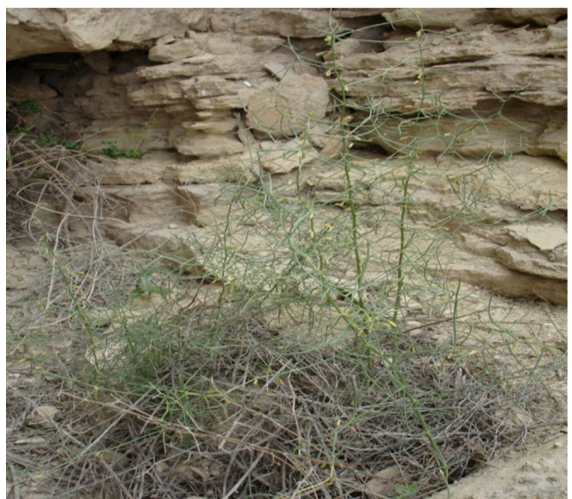

Asparagus turkestanicus Popov

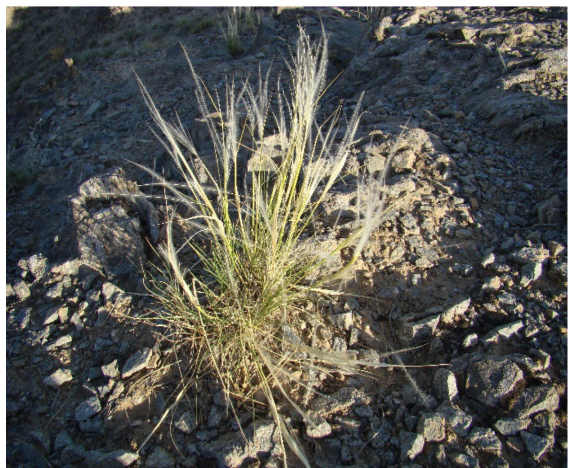

Stipa aktauensis Roshev

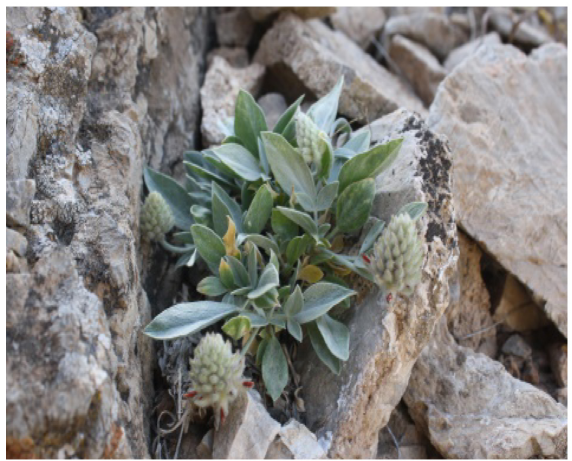

Astragalus centralis E. Sheld

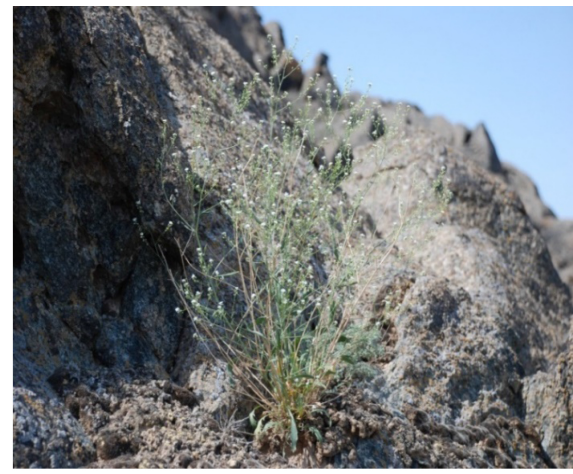

Lepidium subcordatum Botsch.et Vved.

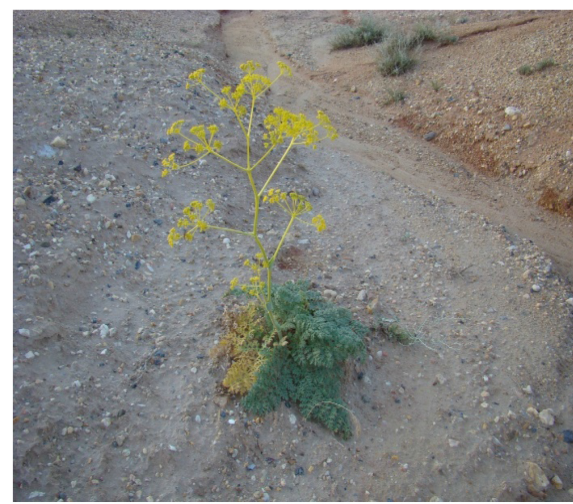

Ferula kyzylkumica Korovin

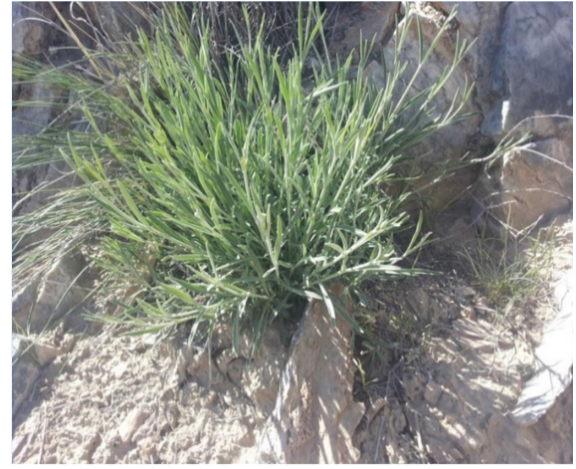

Silene tomentella Schischk

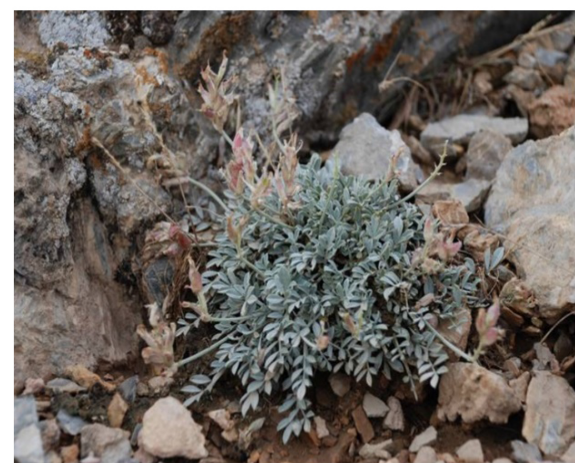

Astragalus holargyreus Popov

Figure 2. Some rare and endemic plants of Sultan-Uvays. 


\section{Conclusions}

Thus, it can be argued that the allocation of the Kyzylkum district with the same name outliers is obvious on the one hand, as well as the close relationship between the flora of Sulton-Uvays and Bukantau on the other. Endemism here has a young progressive character (based mainly on the Western Pamir-Alai and Western Tian-Shan floras). On the other hand, endemic and, in particular, subendemic taxa (essentially endemic to the Turan province) undoubtedly define the flora of Sultan-Uvays as a relict desert flora associated with African flora through Asia Minor.

Information obtained on the distribution of rare and endemic species is used in the preparation of plans for protection measures and monitoring studies, as well as in the preparation of the next editions of the flora of Uzbekistan and the red book of the Republic of Uzbekistan.

\section{Conflicts of Interest}

The author declares no conflicts of interest regarding the publication of this paper.

\section{References}

[1] Lazkov, G.A. and Umralina, A.R. (2015) Endemic and Rare Plant Species of Kyrgyzstan (Atlas). 2nd Edition, Revised and Updated, Ankara, 235 p.

[2] Zakirov, P.K. (1971) Botanical Geography of the Low Mountains of Kyzylkum and the Nuratau Ridge. FAN, Tashkent, 44-122.

[3] Sarbaev, B.S. (1988) Flora and Vegetation of Weeds. Nukus. Karakalpakstan, 12-13.

[4] Korovin, E.P. (1934) Ecological Types of Deserts of Central Asia and Kazakhstan and Prospects of Their Economic Development. Economic Development of the Deserts of Central Asia and Kazakhstan. Tashkent, 121 p.

[5] Kamelin, R.V. (1973) Florogenetic Analysis of the Natural Flora of Mountainous Central Asia. Nauka, L, 356 p.

[6] Khasanov, F.O., Shomuradov, H.F. and Kadyrov, G. (2011) Analysis of the Endemism of the Kyzylkum Flora. Russian Bot. Journal (St. Petersburg), 2, 213-221.

[7] Popov, M.G. (1958) Botanical and Geographical Sketch of the Sultanuizdag Mountains. Selected Works, Ashkhabad, 8-17.

[8] Sherbayev, B.Sh. (1978) Flora of the Remaining Hills and Low Mountains of Karakalpak. FAN, Tashkent, 65.

[9] Abdurakhmanov, R. (1969) Materials on the Flora of Sultanuizdag. Reports of the Academy of Sciences of the Uzbek SSR, No. 7, Toshkent, 50-51.

[10] Khassanov, F.O., Shomuradov, H. and Esankulov, A. (2016) Validation of Some Astragalus L. (Fabaceae) Taxa in the Flora of Middle Asia. Stapfia, 105, 59-63. 